\title{
The effect of doxorubicin on rats that received toxic and carcinogenic benzo(a)pyrene
}

\author{
Didem Cosan $^{1}$, Ayse Basaran ${ }^{1}$, Hasan Veysi Gunes ${ }^{1}$, Irfan Degirmenci ${ }^{1}$, Erinc Aral ${ }^{2}$ \\ ${ }^{1}$ Department of Medical Biology, and ${ }^{2}$ Department of Histology-Embryology \\ Eskisehir Osmangazi University, Medical Faculty, Eskisehir, Turkey
}

\begin{abstract}
Benzo(a)pyrene (B(a)P) is a polycyclic aromatic hydrocarbon with carcinogenic and toxic effects. Doxorubicin is a DNA-interacting drug widely used in chemotherapy. In the present study we investigated the effects of doxorubicin on rats that received benzo(a)pyrene. Sprague-Dawley male rats, 3-4 months old, were divided into 5 groups ( $\mathrm{n}=9$ per group). Group 1 (controls) received normal saline intraperitoneally (i.p.) and intragastrically (i.g.), Group 2 (controls) similarly received corn oil i.p. and i.g., Group 3 received corn oil soluble benzo(a)pyrene (10mg/kg b.wt every 10 days for 40 days), Group 4 received doxorubicin (4mg i.p. on 3 consecutive days), Group 5 received doxorubicin for 3 days (as in group 4) followed by benzo(a)pyrene as in group 3. After twenty-four hours urine samples were collected, heart blood, liver and kidney tissue samples were obtained. Biochemical data were evaluated on urine and blood; liver and kidney tissue samples were investigated histologically. Uric acid, urine creatinine, creatine clearance, urea nitrogen, serum creatinine values, serum glutamic oxaloacetic transaminase (SGOT, AST), serum glutamic pyruvic transaminase (SGPT, ALT), alkaline phosphatase (ALP, AP), superoxide dismutase (SOD), catalase (CAT) activities and malondialdehyde (MDA) levels were significantly different in the 3rd group compared with control groups. Most of the parameters group 5 were statistically similar to control values. Histological appearance of the liver and the kidney tissue samples supported the improvement in the 5 th group. The result of our study indicated that liver and kidney functions impaired with benzo(a)pyrene may be partially restored by doxorubicin.
\end{abstract}

Key words: Benzo(a)pyrene - Doxorubicin - Serum - Superoxide dismutase - Malondialdehyde - Catalase - Kidney - Liver - Rat

\section{Introduction}

Benzo(a)pyrene $[\mathrm{B}(\mathrm{a}) \mathrm{P}]$ is a member of a group of polycyclic aromatic hydrocarbons (PAHs). PAHs are substances causing significant environmental pollution and they have been investigated for their carcinogenic effects [1-6]. These chemical substances have been also proved to cause malignancies in experimental animals [6,7]. In the group of PAHs, $\mathrm{B}(\mathrm{a}) \mathrm{P}$ has the highest potential to cause cancer $[2,4,8,9]$. Furthermore, B(a)P has also mutagenic and teratogenic effects $[2,6,10-12]$. It transforms into (+)-BP-7-8-oxide by the monooxigenase enzyme, into (-)-trans-BP-7,8-dihydrodiol by the epoxide hydrolase enzyme and into (+)-anti-BP-7,8-diol9,10 -epoxide by the monooxigenase enzyme $[1,5]$.

Correspondence: D. Cosan, Büyükdere Mh. Akdogan Sk. Birkonak Sitesi A Blok D 20, 26060 Eskisehir, Turkey; tel.: 05333662680, fax: 02222392220,

e-mail: dcosan@ogu.edu.tr
Thus, this procarcinogen epoxide derivation is formed by $\mathrm{B}(\mathrm{a}) \mathrm{P}$, which is metabolised in the liver. It is the essential carcinogenic metabolite covalently bound to guanine base of the DNA.

Doxorubicin, a drug used in cancer therapy, is a derivative of anthracycline and also known as adriamycin [13]. Doxorubicin is bound to sugar-phosphate structure by cross-linking the DNA after penetrating into close base pairs of the DNA chain in rapidly reproducing cancerous cells. It damages the DNA structure and consequently the RNA synthesis $[14,15]$. Excretion of doxorubicin occurs predominantly by the hepatobiliary route and partially by the kidneys. Elimination of the drug slows down if the liver function is impaired due to the presence of a tumor or some other disease, and it accumulates in the body unless the dose intake is reduced [16].

The objective of this study was to investigate the possible effects of doxorubicin on the hepatic and renal function of rats that received toxic and carcinogenic B(a)P. 
Table 1. Values of urine and creatinine levels in all groups ( $n=9$ in each group). Values expressed as mean \pm SD.

\begin{tabular}{|c|c|c|c|c|c|c|c|}
\hline Group & $\begin{array}{l}\text { Urine volume } \\
\qquad(\mathrm{ml})\end{array}$ & $\mathrm{pH}$ & $\begin{array}{l}\text { Uric acid } \\
(\mathrm{mg} / \mathrm{dl})\end{array}$ & $\begin{array}{l}\text { Urea nitrogen } \\
\qquad(\mathrm{mg} / \mathrm{dl})\end{array}$ & $\begin{array}{l}\text { Urine creatinine } \\
\qquad(\mathrm{mg} / \mathrm{dl})\end{array}$ & $\begin{array}{l}\text { Creatinine } \\
\text { clearance } \\
(\mathrm{ml} / \mathrm{min})\end{array}$ & $\begin{array}{c}\text { Serum } \\
\text { creatinine } \\
(\mathrm{mg} / \mathrm{dl})\end{array}$ \\
\hline I & $\begin{array}{c}9.75 \\
\pm 0.14\end{array}$ & $\begin{array}{c}07.55 \\
\pm 0.99\end{array}$ & $\begin{array}{r}10.32 \\
\pm 0.79\end{array}$ & $\begin{array}{l}1690 \\
\pm 69\end{array}$ & $\begin{array}{r}75.98 \\
\pm 3.19\end{array}$ & $\begin{array}{c}0.38 \\
\pm 0.09\end{array}$ & $\begin{array}{c}1.60 \\
\pm 0.32\end{array}$ \\
\hline II & $\begin{array}{c}9.69 \\
\pm 0.24\end{array}$ & $\begin{array}{c}07.55 \\
\pm 0.50\end{array}$ & $\begin{array}{l}10.36 \\
\pm 0.97\end{array}$ & $\begin{array}{l}1702 \\
\pm 78\end{array}$ & $\begin{array}{r}75.39 \\
\pm 2.42\end{array}$ & $\begin{array}{c}0.33 \\
\pm 0.09\end{array}$ & $\begin{array}{c}1.65 \\
\pm 0.24\end{array}$ \\
\hline III & $\begin{array}{c}9.83 \\
\pm 0.26\end{array}$ & $\begin{array}{c}06.06 \\
\pm 0.49 * * *\end{array}$ & $\begin{array}{c}08.92 \\
\pm 0.54 * * *\end{array}$ & $\begin{array}{c}1548 \\
\pm 62 * * *\end{array}$ & $\begin{array}{c}65.14 \\
\pm 2.65^{* * *}\end{array}$ & $\begin{array}{c}0.19 \\
\pm 0.05^{\text {*** }}\end{array}$ & $\begin{array}{c}2.71 \\
\pm 0.30^{* * * *}\end{array}$ \\
\hline IV & $\begin{array}{c}9.15 \\
\pm 0.28^{* * *} \\
\end{array}$ & $\begin{array}{l}07.51 \\
\pm 0.97 \\
\end{array}$ & $\begin{array}{c}09.45 \\
\pm 0.58 * \\
\end{array}$ & $\begin{array}{r}1621 \\
\pm 42^{*} \\
\end{array}$ & $\begin{array}{r}72.22 \\
\pm 4.45^{*} \\
\end{array}$ & $\begin{array}{c}0.26 \\
\pm 0.09 * \\
\end{array}$ & $\begin{array}{c}1.99 \\
\pm 0.41^{*} \\
\end{array}$ \\
\hline V & $\begin{array}{c}9.46 \\
\pm 0.14^{* *}\end{array}$ & $\begin{array}{r}07.95 \\
\pm 0.85\end{array}$ & $\begin{array}{c}09.14 \\
\pm 0.90 * *\end{array}$ & $\begin{array}{c}1567 \\
\pm 73^{* * *}\end{array}$ & $\begin{array}{c}71.17 \\
\pm 2.00 * *\end{array}$ & $\begin{array}{c}0.25 \\
\pm 0.04 * *\end{array}$ & $\begin{array}{c}2.13 \\
\pm 0.22 * *\end{array}$ \\
\hline
\end{tabular}

$\mathrm{p}<0.05^{*}, \mathrm{p}<0.01 * *, \mathrm{p}<0.0001^{* * *}$

Table 2. Levels of hemoglobin, hematocrit, AST, ALT and AP in all groups ( $\mathrm{n}=9$ in each groups). Values expressed as mean \pm SD.

\begin{tabular}{|c|c|c|c|c|c|}
\hline Group & $\begin{array}{l}\text { Hemoglobin } \\
\qquad(\mathrm{g} / \mathrm{dl})\end{array}$ & $\begin{array}{c}\text { Hematocrit } \\
(\%)\end{array}$ & $\begin{array}{c}\text { Ast } \\
(\mathrm{U} / 1)\end{array}$ & $\begin{array}{c}\text { Alt } \\
(\mathrm{U} / 1)\end{array}$ & $\begin{array}{c}\mathrm{AP} \\
(\mathrm{U} / 1)\end{array}$ \\
\hline I & $\begin{array}{r}24.33 \\
\pm 3.85\end{array}$ & $\begin{array}{r}47.70 \\
\pm 2.26\end{array}$ & $\begin{array}{r}50.88 \\
\pm 7.16\end{array}$ & $\begin{array}{r}14.84 \\
\pm 3.72\end{array}$ & $\begin{array}{r}63.43 \\
\pm 5.85\end{array}$ \\
\hline II & $\begin{array}{r}26.60 \\
\pm 6.93\end{array}$ & $\begin{array}{r}48.40 \\
\pm 6.39\end{array}$ & $\begin{array}{r}50.49 \\
\pm 7.85\end{array}$ & $\begin{array}{r}14.05 \\
\pm 1.83\end{array}$ & $\begin{array}{r}59.72 \\
\pm 6.41\end{array}$ \\
\hline III & $\begin{array}{r}27.96 \\
\pm 5.36\end{array}$ & $\begin{array}{r}48.73 \\
\pm 2.65\end{array}$ & $\begin{array}{c}68.21 \\
\pm 4.02 * * *\end{array}$ & $\begin{array}{c}28.64 \\
\pm 7.47^{* * *}\end{array}$ & $\begin{array}{c}36.92 \\
\pm 2.69^{* * *}\end{array}$ \\
\hline IV & $\begin{array}{l}23.58 \\
\pm 5.90\end{array}$ & $\begin{array}{r}45.75 \\
\pm 4.03\end{array}$ & $\begin{array}{l}52.04 \\
\pm 7.07\end{array}$ & $\begin{array}{c}21.25 \\
\pm 8,31^{*}\end{array}$ & $\begin{array}{c}57.63 \\
\pm 4.85^{*}\end{array}$ \\
\hline $\mathrm{V}$ & $\begin{array}{l}24.51 \\
\pm 1.57\end{array}$ & $\begin{array}{l}47.75 \\
\pm 4.65\end{array}$ & $\begin{array}{l}52.55 \\
\pm 2.37\end{array}$ & $\begin{array}{c}24.23 \\
\pm 7.33^{* *}\end{array}$ & $\begin{array}{c}55.86 \\
\pm 3.24 * *\end{array}$ \\
\hline
\end{tabular}

$\mathrm{p}<0.05^{*}, \mathrm{p}<0.01 * *, \mathrm{p}<0.001 * * *$

\section{Material and methods}

Animals. Forty-five male Sprague-Dawley rats weighing 250$350 \mathrm{~g}$ were selected from a group of healthy 3-4 month-old rats. They were divided into five groups containing 9 rats each. The first group received normal saline intraperitoneally (i.p.) and intragastrically (i.g.); the second group received corn oil (i.p. and i.g.). In the third group, $10 \mathrm{mg} / \mathrm{kg} \mathrm{B}(\mathrm{a}) \mathrm{P}$ administered intragastrically once in 10 days for 40 days (total $40 \mathrm{mg} / \mathrm{kg}$ ). The fourth group received daily $4 \mathrm{mg} / \mathrm{kg}$ doxorubicin (i.p.) for 3 consecutive days (total $12 \mathrm{mg} / \mathrm{kg}$ ). The fifth group received daily $4 \mathrm{mg} / \mathrm{kg}$ doxorubicin (i.p.) for 3 consecutive days (total $12 \mathrm{mg} / \mathrm{kg}$ ) following $10 \mathrm{mg} / \mathrm{kg} \mathrm{B}(\mathrm{a}) \mathrm{P}$ (i.g.) once in 10 days for 40 days (total $40 \mathrm{mg} / \mathrm{kg}$ ). Benzo(a)pyrene was dissolved in corn oil, and doxorubicin was dissolved in distilled water. Substances were prepared fresh on the day they were applied into rats. Throughout the period of the study, the rats were allowed access to food and water ad libitum. Other cleaning considerations in places where animals live were provided, and it care was taken that animals were fed with sufficient food and water.

Material samples. At the end of the experiment, each rat was housed in metabolic cages to collect 24-hour urine samples. Fol- lowing urine collection, blood samples were obtained from the heart under ether anaesthesia. Ether anaesthesia was used in all groups including control group. This short acting agent was preferred due to its well-known predicted results. Liver and kidney tissue samples of all rats were quickly fixed in $10 \%$ neutral buffered formalin for histology. Tissue samples were embedded in paraffin, and tissue sections (5 $\mu \mathrm{m}$ thick) were then stained with hematoxylin and eosin. After volume and $\mathrm{pH}$ values of collected urine samples were determined, uric acid (Caraway's modified method), urea nitrogen (Urease-nesslerisation method) and creatinine (Jaffe alkaline picrate assay) values were measured spectrophotometrically. Hemoglobin (oxyhemoglobin method) and hematocrit values of blood samples taken inside hemoglobin and hematocrit pipettes were determined. Serum creatinine, AST (SGOT Chroma test kit), ALT (SGPT Chroma test kit) and AP (ALP Chroma test kit) activities of blood samples kept inside normal tubes were measured spectrophotometrically. Levels of superoxide dismutase (SOD) [17], catalase activity (CAT) [18] and malondialdehyde (MDA) (TBA reaction) [19] products of lipid peroxidation, were determined by preparing hemolysates of blood samples taken into EDTA tubes. All spectrophotometric measurements were done by means of Shimadzu UV-1601 digital spectrophotometer (Shimadzu Corp., Kyoto, Japan). 
Ethical issues. This study was approved by the local ethics committee of Eskisehir Osmangazi University of Animal Experiments.

Statistical analysis. All data were expressed as means \pm standard deviation. Differences between the means of various results were assessed for statistical significance by ANOVA, followed by Tukey's multiple comparison tests. A p value $<0.05$ was considered to indicate statistical significance.

\section{Results}

All parameters between the saline group and the corn oil group (control groups) were found statistically insignificant. Urine volumes of group $4(p<0.001)$ and group $5(\mathrm{p}<0.01)$ decreased statistically compared with control groups, and the $\mathrm{pH}$ level was decreased only in group $3(p<0.001)$ compared with control groups. Urine values for uric acid, urea nitrogen, creatinine and creatine clearance of group $3(p<0.001)$, group 4 $(\mathrm{p}<0.05)$ and group $5(\mathrm{p}<0.01)$ were decreased, and serum creatinine values were increased in group 3 $(\mathrm{p}<0.001)$, group $4(\mathrm{p}<0.05)$ and group $5(\mathrm{p}<0.01)$ compared with control groups (Table 1). Values for hemoglobin and hematocrit were statistically insignificant between the control and other groups. While AST enzyme activity increased only in group $3(p<0.001)$, ALT enzyme activity increased in group $3(p<0.001)$, group $4(\mathrm{p}<0.05)$ and group $5(\mathrm{p}<0.01)$ compared with control groups. AP decreased in group $3(\mathrm{p}<0.001)$, group $4(\mathrm{p}<0.05)$ and group $5(\mathrm{p}<0.01)$ (Table 2$)$. SOD and MDA values increased in group $3(\mathrm{p}<0.001)$ and group $5(\mathrm{p}<0.05)$ compared with control groups, but CAT decreased in group $3(\mathrm{p}<0.001)$, group $4(\mathrm{p}<0.05)$ and group $5(\mathrm{p}<0.01)$ (Table 3$)$.

Histology of sections of liver and kidney in the control and corn oil groups was normal (Fig. 1 and 2). In the $\mathrm{B}(\mathrm{a}) \mathrm{P}$ group, deformations occurred in the cordlike arrangements of hepatocytes seen in the liver. Congestion of sinusoids in some areas and Kupffer cell hyperplasia were also observed. Furthermore, vacuolar degenerations of hepatocytes in the periportal zone (Fig. 3) were common, and increased numbers of polymorphonuclear cells and mononuclear cells were also noted. Hyperemia was observed in some places of kidney cross-sections; vacuolization and desquamation of proximal tubule cells and dilatation of some tubules were also observed (Fig. 4). These findings were insignificant in liver and kidney cross sections of the doxorubicin treated group. In the group where $\mathrm{B}(\mathrm{a}) \mathrm{P}$ and doxorubicin were administered, hepatotoxicity and nephrotoxicity partly decreased compared to the B(a)P group (Fig. 5 and 6).

\section{Discussion}

Increases or decreases in urine uric acid, serum creatinine and creatinine clearance values indicate renal failure, and decreases in urea nitrogen value indicate both
Table 3. Levels of SOD, CAT and MDA in all groups ( $\mathrm{n}=9$ in each groups). Values expressed as mean $\pm \mathrm{SD}$.

\begin{tabular}{|c|c|c|c|}
\hline \multirow{2}{*}{ Group } & \multicolumn{3}{|c|}{ Erythrocyte } \\
\cline { 2 - 4 } & SOD U/gHb & CAT U/1 & MDA U/gHb \\
\hline \multirow{2}{*}{ I } & 3408 & 210.99 & 97.80 \\
& \pm 350 & \pm 9.11 & \pm 05.33 \\
\hline \multirow{2}{*}{ II } & 3581 & 210.70 & 95.15 \\
& \pm 360 & \pm 4.42 & \pm 05.11 \\
\hline \multirow{2}{*}{ III } & 5742 & 138.13 & 132.28 \\
& $\pm 569^{* * *}$ & $\pm 6.68^{* * *}$ & $\pm 17.89^{* * *}$ \\
\hline \multirow{2}{*}{ IV } & 3806 & 201.51 & 103.35 \\
& $\pm 330^{*}$ & $\pm 4.50^{*}$ & $\pm 03.53^{*}$ \\
\hline \multirow{2}{*}{ V } & 4056 & 199.75 & 106.94 \\
& $\pm 546 * *$ & $\pm 3.75^{* *}$ & $\pm 04.75^{* *}$ \\
\hline
\end{tabular}

renal and hepatic failure [20]. Review of the literature on studies performed with B(a)P, lack any reports investigating uric acid and urea nitrogen in urine. 6nitrochrysene (6-NC), an environmental contaminant like B(a)P, has been shown to be carcinogenic in the liver and the colon [21]. Results of their study showed decreased serum uric acid and blood urea nitrogen values in Syrian golden hamsters that received 6-NC. In another study, blood urea nitrogen and serum creatinine values in Sprague-Dawley rats, which received 10 $\mathrm{mg} / \mathrm{kg} \mathrm{B}(\mathrm{a}) \mathrm{P}$ i.p. once a week for 5 weeks, did not differ from the control group [22]. In our study, the application of $10 \mathrm{mg} / \mathrm{kg} \mathrm{B}$ (a)P i.g. once in 10 days for 40 days reduced urine uric acid, urea nitrogen, creatinine and creatine clearance, but serum creatinine values were increased.

It has been reported that increased blood urea nitrogen (BUN) and serum creatinine levels, decreased creatine clearance in doxorubicin treated Sprague-Dawley rats compared to the control [23]. Another study has indicated significant serum creatine, uric acid and BUN increase in doxorubicin-treated rats compared to the control. In doxorubicin-treated Wistar rats, urea nitrogen and serum creatinine levels increased [24]. Although decreases in serum creatinine and creatinine clearance in these studies are similar to our results, other findings differ from ours. In our doxorubicintreated group, uric acid, urine urea nitrogen, urine creatinine and creatine clearance decreased, and serum creatinine value increased.

A study performed on Wistar rats has noted increases in AST, ALT and AP enzyme activities in the group treated with $10 \mathrm{mg} / \mathrm{rat} \mathrm{B}(\mathrm{a}) \mathrm{P}$ [25]. As our study indicated a decrease in AP, this research and our study indicate difference for AP values. Another study performed on Wistar Lewis rats has indicated no difference in AST activities between the control and the group treated with $1.5 \mathrm{mg} / \mathrm{kg}$ doxorubicin i.p. 2 times 

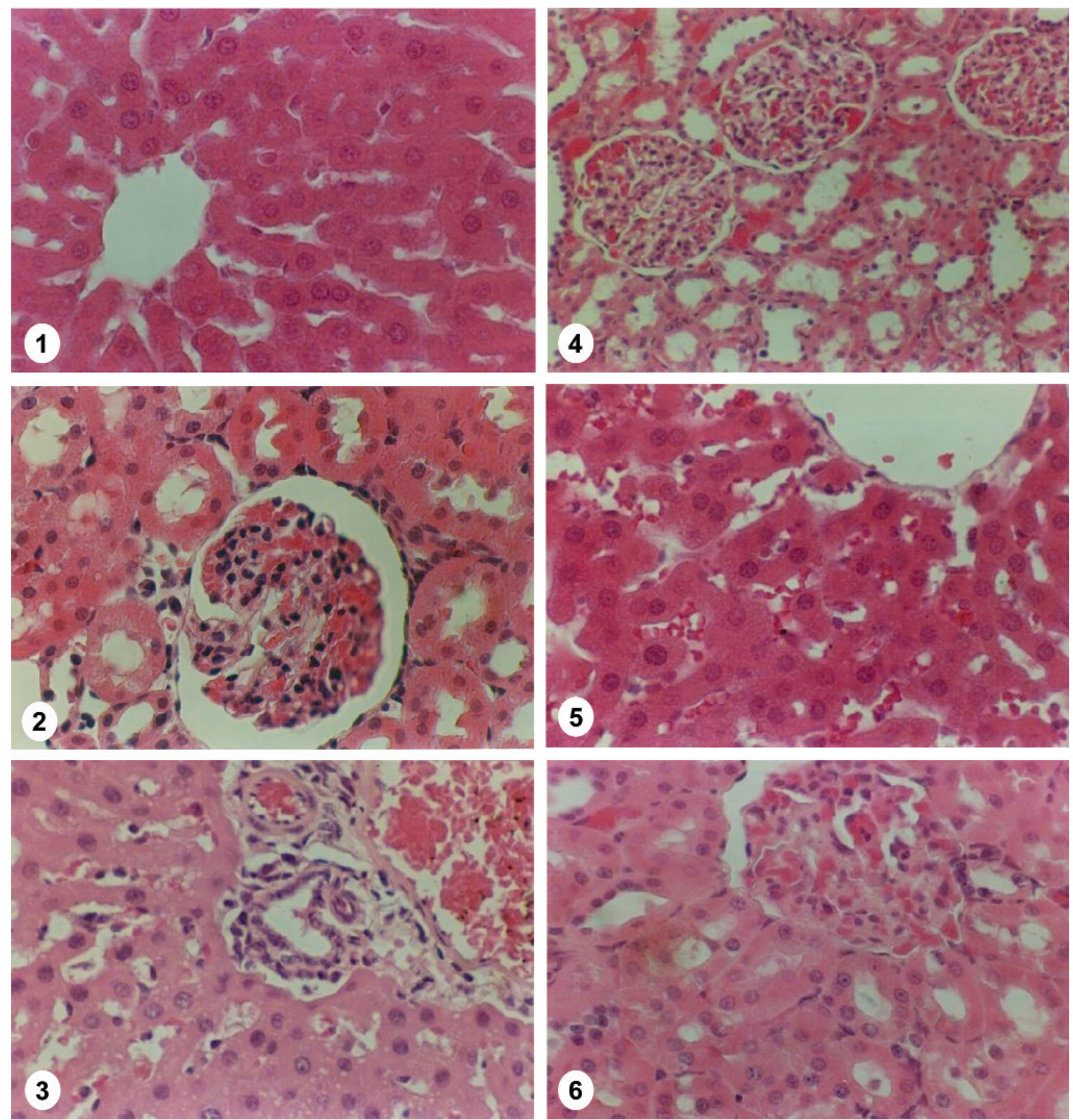

Fig. 1. Photomicrograph showing liver tissue section of the first group $(H+E$, magnification $\times 132)$. Fig. 2. Photomicrograph showing renal cortex of the rat from the first group $(\mathrm{H}+\mathrm{E}$, magnification $\times 132)$. Fig. 3. Photomicrograph showing liver tissue section of the rat from $3 \mathrm{rd}$ group. Note the expanded Kiernan areas, increasing of the fiber structures and extensive hydropic degenerations in hepatocytes $(\mathrm{H}+\mathrm{E}$, magnification $\times 132$ ). Fig. 4. Photomicrograph showing renal section of the rat from 3rd group. Note the hyperaemia, dilatations in distal tubules and desquamations $(\mathrm{H}+\mathrm{E}$, magnification $\times 66)$. Fig. 5. Photomicrograph showing liver tissue section of the rat from 5 th group. Note the slight sinusoidal congestions, hydropic degenerations in some hepatocytes $(\mathrm{H}+\mathrm{E}$, magnification $\times 132)$. Fig. 6. Photomicrograph showing renal cortex of the rat from 5th group. Note the slight hyperemias, and proximal tubules are observed nearly normal appearance compared with the appearances in control group $(\mathrm{H}+\mathrm{E}$, magnification $\times 132)$.

a week, and it has also indicated a decrease in ALT and AP activities compared with controls [26]. AST and AP values in our study are in accordance with their results, but the increase in ALT value differs from the results of their study.
In Sprague-Dawley rats that received $20 \mathrm{mg} / \mathrm{kg}$ B(a)P, SOD activity in erythrocytes has been measured at different times. SOD activity has significantly increased 6 hours after the application; it has peaked after 24 hours and then reached control levels after 96 
hours. CAT activity has also significantly increased 12 hours after application; it peaked at 24 hours and reached control levels after 96 hours. MDA was not changed after 6 hours; increased significantly at 12 hours, and the increase continued more than 96 hours $[27,28]$. In another study performed on Wistar rats, SOD activity has been significantly decreased in $\mathrm{B}(\mathrm{a}) \mathrm{P}$ treated group [25]. It has been also reported that 7.5 $\mathrm{mg} / \mathrm{kg}$ doxorubicin induces superoxide dismutase [14]. In our study, SOD activity and MDA increased while CAT activity decreased following a long-term B(a)P treatment, and SOD activity slightly decreased in 4 $\mathrm{mg} / \mathrm{kg}$ doxorubicin treated group.

In Hodgkin's lymphoma patients treated with doxorubicin, bleomycin, vincristine and dexamethasone (ABVD treatment protocol), serum SOD and CAT levels decreased and MDA increased on day 1 and day 7 compared to the pre-treatment period [29]. Our study showed that SOD and MDA values in rats treated with doxorubicin after $\mathrm{B}(\mathrm{a}) \mathrm{P}$ application were higher than the controls at the end of the experiment, and that CAT value was lower compared to controls.

In our study, normal classical lobule and portal area structure was observed in liver cross sections of the control groups. However, there was quite remarkable degeneration of hepatocytes in the periportal areas of group 3 and hydropic degeneration of hepatocytes in group 4. Hepatotoxicity was considerably decreased and common parenchymal degenerations were improved in the doxorubicin and $\mathrm{B}(\mathrm{a}) \mathrm{P}$ treated group 5 compared to the $\mathrm{B}(\mathrm{a}) \mathrm{P}$ applied group 3. Normal cortex and medulla structures were observed in kidney sections of the control groups. Hyperemia was observed in some places of intertubular vessels in kidney cortex and medulla of group 3, and there was also vacuolisation and desquamation in proximal tubule cells. Hydropic degeneration and hyperemia was observed in some proximal tubule cells of group 4 , though not as much as the benzo(a)pyrene group. Hepatotoxicity and nephrotoxicity were considerably decreased in group 5, and the degenerative changes seen in kidney sections group 5 were interpreted as reversible.

In our study, B(a)P application to rats damaged liver and kidney functions as measured by urine parameters, AST, ALT and AP levels. The histological appearance of liver and kidney also supported all these findings. However, there were some negative changes in the doxorubicin-treated group. Much worse effects expected to occur when benzo(a)pyrene and doxorubicin are used together did not occur, and doxorubicin was shown not to have further destructive effect on already damaged tissues or functions. We conclude that tissue degeneration due to benzo(a)pyrene application may be partially improved following doxorubicin treatment. We believe that comparative data obtained from other future investigations would advance our knowledge of the effects of doxorubicin on the pathogenesis of $\mathrm{B}(\mathrm{a}) \mathrm{P}$ toxicity.

\section{References}

[1] Cavalieri EL, Roman EG, Devanesan PD, Cremonesi P, Cerny RL, Groos ML, Bodell WJ. Binding of benzo(a)pyrene to DNA by cytochrome P-450 catalyzed one-electron oxidation in rat liver microsomes and nuclei. Biochemistry. 1990; 29:4820-4827.

[2] Fujita I, Sindhu RK, Kikkawa Y. Hepatic cytochrome P450 enzyme imprinting in adult rat by neonetal benzo(a)pyrene administration. Pediatr Res. 1995;37:646-651.

[3] Garner RC, Stanton CA, Martin CN, Harris CC, Grafstrom RC. Rat and human explant metabolism, binding studies, and DNA adduct analysis of benzo(a)pyrene and its 6-nitro derivative. Cancer Res. 1985;45:6225-6231.

[4] Obi FO, Billett MA. Preferential binding of the carcinogen benzo(a)pyrene to proteins of the nuclear matrix. Carcinogenesis. 1991;12:481-486.

[5] Phillips DH. Fifty years of benzo(a)pyrene. Nature. 1983; 303:468-472.

[6] Willems MI, Roggeband R, Baan RA, Wilmer JW, De Raat WK, Lohman PH. Monitoring the exposure of rats to benzo(a)pyrene by the determination of mutagenic activity in excreta, chorosome aberrations and sister chromatid exchanges in peripheral blood cells, and DNA adducts in peripheral blood lymphocytes and liver. Mutagenesis. 1991; 6:151-158.

[ 7] Tudek B, Bird RP, Bruce WR. Foci of abberant crypts in the colons of mice and rats exposed to carcinogens associated with foods. Cancer Res. 1989;49:1236-1240.

[ 8] Rudo KM, Dauterman WC, Langenbach R. Human and rat kidney cell metabolism of 2- acetylaminofluorene and benzo(a)pyrene. Cancer Res. 1989;49:1187-1192.

[ 9] Tan B, Chu FL. Effects of palm carotenoids in rat hepatic cytochrome P450 - mediated benzo(a)pyrene metabolism. Am J Clin Nutr. 1991;53:1071S-1075S.

[10] Bevan DR, Manger WE. Effect of particulates on metabolism and mutagenicity of benzo(a) pyrene. Mutagenesis. 1985;56: 13-28.

[11] Nanno M, Morotomi M, Takayama H, Kuroshima T, Tanaka R, Mutai M. Mutagenic activation of biliary metabolites of benzo(a)pyrene by - glucuronidase - positive bacteria in human faeces. $J$ Med Microbiol. 1986;22:351-355.

[12] Utesch D, Glatt H, Oesch F. Rat hepatocyte-mediated bacterial mutagenicity in relation to the carcinogenic potency of benzo(a)anthracene, and twenty-five methylated derivatives. Cancer Res. 1987;47:1509-1515.

[13] Raiczyk BG, Pinto J. Inhibition of flavin metabolism by adriamycin in skeletal muscle. Biochem Pharmacol. 1988;37:1741-1744.

[14] Okasora T, Takikawa T, Utsunomiya Y, Senoh I, Hayashibara H, Shiraki K, Kasagi T, Shimizu F. Suppressive effect of superoxide dismutase on adriamycin nephropathy. Nephron. 1992;60:199-203.

[15] Rosselli F, Zaccaro L, Venturi M, Rossi AM. Persistence of drug -induced chromosome aberrations in peripheral blood lymphocytes of the rat. Mutat Res. 1990;232:107-114.

[16] Mycek MJ, Harvey RA, Champe PC, Fisher BD, Cooper M, Berkman K. Lippincott's Illustrated Reviews Pharmacology. 1997; 2nd edition, Lippincott-Raven, Philadelphia.

[17] Sun Y, Oberley LW, Li Y. A simple method for clinical assay of superoxide dismutase. Clin Chem. 1988;34:497-500.

[18] Ohkawa H, Ohishi N, Yagi K. Assay for lipid peroxidation in animal tissues by thiobarbituric acid reaction. Anal Biochem. 1979;95:351-358. 
[19] Goth L. A simple method for determination of serum catalase activity and revision of reference range. Clin Chim Acta. 1991;196:143-151.

[20] Murray RK, Granner DK, Mayes PA, Rodwell VW. Harper's Biochemistry. 1990; 22nd Ed., Appleton \& Lange, San Mateo, CA.

[21] Chen R-M, Chou MC Queen T-H. Induction of cytochrome P450 1A in hamster liver and lung by 6-Nitrochrysene. Arch Toxicol. 1998;72:395-401.

[22] Valentovic MA, Alejandro N, Betts Carpenter A, Brown PI, Ramos K. Streptozotocin (STZ) diabetes enhances benzo(alpha)pyrene induced renal injury in Sprague Dawley rats. Toxicol Lett. 2006;164:214-220.

[23] Nagano N, Miyata S, Obana S, Ozai M, Kobayashi N, Fukushima N, Burke SK, Wada M. Sevelamer hydrochloride (Renagel), a non-calcaemic phosphate binder, arrest parathyroid gland gland hyperplasia in rats with progressive chronic renal insufficiency. Nephrol Dial Transplant. 2001;16:1870-1878.

[24] Oz E, Ilhan M. Effects of melatonin in reducing the toxic effects of doxorubicin. Mol Cell Biochem. 2006;286:11-15.

[25] Lakshmi B, Ajith TA, Jose N, Janardhanan KK. Antimutagenic activity of methanolic extract of ganoderma lucidum and its effect on hepatic damage caused by benzo[a]pyrene. J Ethnopharmacol. 2006;107:297-303.

[26] Kunitomo M, Yamaguchi Y, Matsushima K, Futagawa Y, Bando Y. Hyperlipidemic effects of adriamycin in rats. Jpn J Pharmacol. 1985;39:323-329.

[27] Kim HS, Kwack SJ, Lee BM. Lipid peroxidation, antioxidant enzymes, and benzo[a]pyrene-quinones in the blood of rats treated with benzo[a]pyrene. Chem Biol Interact. 2000;127: 139-150.

[28] Kim KB, Lee BM. Oxidative stress to DNA, protein, and antioxidant enzymes (superoxide dismutase and catalase) in rats treated with benzo(a)pyrene. Cancer Lett. 1997;113:205212.

[29] Kaya E, Keskin K, Aydogdu I, Kuku I, Bayraktar N, Erkut MA. Oxidant/antioxidant parameters and their relationship with chemotherapy in Hodgkin's lymphoma. $J$ Int Med Res. 2005;33:687-692.

Submitted: 6 May, 2007 Accepted after reviews: 23 January, 2008 